\title{
Risk factors and complications in type 2 diabetes outpatients
}

\author{
Ellen Fernandes Flávio Silva ${ }^{1}$, Cristiane Maria Mendes Ferreira ${ }^{2 *}$, Lucineia de Pinho $^{3}$ \\ ${ }^{1}$ Medical Student, Faculdades Unidas do Norte de Minas (Funorte), Montes Claros, MG, Brazil \\ ${ }^{2}$ Endocrinologist, Universidade Estadual de Montes Claros (Unimontes), Montes Claros, MG, Brazil \\ ${ }^{3} \mathrm{PhD}$ in Health Sciences, Unimontes and Funorte, Montes Claros, MG, Brazil
}

Study conducted at Universidade Estadual de Montes Claros (Unimontes) Montes Claros, MG, Brazil

Article received: $11 / 13 / 2016$ Accepted for publication: $12 / 19 / 2016$

*Correspondence:

Address: Av. Dr. Ruy Braga, $\mathrm{s} / \mathrm{n}$ Montes Claros, MG - Brazil

Postal code: 39401-089 cristianemariamf@gmail.com

\section{SUMMARY}

Objective: Our study investigated type 2 diabetes mellitus (T2DM) outpatients attending a university hospital in Montes Claros, MG, to estimate the prevalence of risk factors and their association with diabetes complications.

Method: This was a quantitative, documental, retrospective and analytical study. Medical records of 95 outpatients with T2DM treated in this hospital from 2011 to 2015 were analyzed. Data were collected according to a structured questionnaire surveying sociodemographic, anthropometric and biochemical data and clinical and lifestyle aspects. Regression analysis was used to evaluate the association between risk factor variables and complications.

Results: With a mean age of 54 years, the study population showed irregular blood glucose control, despite the use of hypoglycemic medication, and did not have a healthy lifestyle. The main complication reported was high blood pressure (HBP), occurring in $70.9 \%$ of patients. The prevalence of complications was positively associated with patients receiving insulin treatment $(\mathrm{p}=0.042)$ and multidisciplinary monitoring $(\mathrm{p}=0.050)$.

Conclusion: The associations identified reflect the condition of patients that were already treating diabetes and its complications, especially HBP. The characteristics of the study population indicate the need to improve clinical follow-up and increase motivation for healthy behaviors.

Keywords: diabetes mellitus type 2, diabetes complications, risk factors.

\section{INTRODUCTION}

In Brazil, socioeconomic transformations have led to an aging population. Some epidemiological changes that result from this phenomenon are a decline in the occurrence of infectious-parasitic diseases and the predominance of chronic non-communicable diseases such as type 2 diabetes mellitus (T2DM). ${ }^{1,2}$

The occurrence of T2DM in the Brazilian population has increased considerably in recent years, and this is currently one of the most prevalent chronic diseases in the country. This increase is probably related to habits of the modern world, such as the consumption of high-energy diets and sedentary lifestyle, as well as increased life expectancy, development of obesity and difficult access to health services. In addition, there are genetic factors that favor the disease, which makes some people more susceptible to it., ${ }^{2,3}$

Diabetes is a pathology that stands out for the potential of developing long-term complications. ${ }^{4}$ At a macro- vascular level, patients with diabetes may develop ischemic heart disease, cerebrovascular disease and peripheral vascular disease, which often lead to morbidity and mortality. At a microvascular level, diabetes can lead to vision impairment (retinopathy), kidney disease (nephropathy) and neuronal damage (neuropathies), which are more common causes of irreversible blindness, chronic kidney disease and non-traumatic lower limb amputations. ${ }^{6-8}$ This proves the severity of diabetes, as the reported complications affect different systems in the body and the sequelae can severely compromise the patients' quality of life. ${ }^{2}$

$\mathrm{T} 2 \mathrm{DM}$ can be considered one of the chronic diseases of greater impact for the public health system. In addition to causing a high degree of morbidity and mortality, the metabolic control of diabetes and the treatment of its complications have a high cost for health services. ${ }^{4,9}$ Considering the prognosis of individuals who develop physiological changes as a consequence of T2DM, our study 
investigated patients with T2DM treated at a university hospital in Montes Claros, state of Minas Gerais, Brazil, in order to estimate the prevalence of risk factors and their association with diabetes complications. The knowledge of the local population is important to direct actions to prevent the undesirable consequences of this disease.

\section{Method}

This is a quantitative, documentary, retrospective and analytical study. Our study was developed at the outpatient clinic for patients with T2DM linked to the Clemente de Faria University Hospital, in Montes Claros, state of Minas Gerais, Brazil. The target population included all adult patients, of both genders, diagnosed with T2DM and treated at the outpatient clinic from 2011 to 2015. Cases of chronic complications (diabetic nephropathy and secondary hypertension), aged over 65 years, and presenting only one outpatient visit or incomplete data in the medical records were excluded. In all, the records of 95 patients were evaluated.

Data were collected directly from the patients' medical charts, according to a structured script. Data included sociodemographics (age, marital status and gender), as well as anthropometric and biochemical (weight, fasting blood glucose, HbA1c or glycohemoglobin, total cholesterol, LDL-cholesterol, HDL-cholesterol, triglycerides, systolic and diastolic blood pressure) information. Clinical (disease duration, heredity, type of treatment, professional monitoring and presence of complications) and lifestyle (alcoholism, smoking and eating habits) information were also collected. Morbidities identified as complications were those indicated in the medical record, properly diagnosed and resulting from diabetes, including cardiovascular diseases, hypertension, retinopathy and diabetic nephropathy.

Data were analyzed using Statistical Package for the Social Sciences for Windows ${ }^{\circledR}$, software version 18.0. The results were described as mean \pm standard deviation $(\mathrm{SD})$, or absolute numbers and percentage.

Statistical analysis of the association between independent factors and the dependent variable "presence of complications" was done using binary, univariate and multiple logistic regression models. For the multiple analysis, variables that presented a descriptive level below $20 \%$ were tested. Variables that presented statistical significance of up to $5 \%$ were maintained in the final model.

Our study is in accordance with the ethical precepts of Resolution 466/12 of the National Health Council and was approved by the Research Ethics Committee of the University of Montes Claros (Protocol of approval No. 473,558/2013).

\section{Results}

The mean age of the 95 patients in our population was $54.21 \pm 12.77$ years. Almost half were female $(52.6 \%)$ and most were married (68.4\%) (Table 1). According to clinical and lifestyle data, the patients had a median time since the diagnosis of T2DM of 11 years (ranging from one to 30 years). More than three-quarters of the population did not smoke (76.8\%) and were not alcohol-dependent (78.9\%). Only $23.6 \%$ reported consuming a regular diet, and nutritional monitoring was performed by only $17.8 \%$. The use of oral and insulin hypoglycemic agents was reported by approximately half of the patients (Table 2 ).

\begin{tabular}{|c|c|}
\hline Variables & N (\%) \\
\hline \multicolumn{2}{|l|}{ Sex } \\
\hline Male & $45(47.4)$ \\
\hline Female & $50(52.6)$ \\
\hline \multicolumn{2}{|l|}{ Age range (years) } \\
\hline $20-30$ & $04(4.2)$ \\
\hline $31-40$ & $06(6.3)$ \\
\hline $41-50$ & $22(23.2)$ \\
\hline $51-60$ & $33(34.7)$ \\
\hline$\geq 61$ & $30(31.6)$ \\
\hline \multicolumn{2}{|l|}{ Marital status } \\
\hline Married & $54(56.8)$ \\
\hline Common-law partner & $11(11.6)$ \\
\hline Single & $15(15.8)$ \\
\hline Divorced & $7(7.5)$ \\
\hline Widow(er) & $3(3.3)$ \\
\hline
\end{tabular}

TABLE 2 Clinical and lifestyle characterization of patients with type 2 diabetes mellitus.

\begin{tabular}{ll} 
Variables & $\mathbf{N}(\%)$ \\
\hline Time since diagnosis (years) & \\
\hline$\leq 5$ & $24(25.3)$ \\
\hline $6-10$ & $19(20.0)$ \\
\hline $11-15$ & $25(26.3)$ \\
\hline $16-20$ & $13(13.7)$ \\
\hline $21-25$ & $5(5.3)$ \\
\hline$\geq 26$ & $9(9.4)$ \\
\hline Smoker & \\
\hline No & $67(70.5)$ \\
\hline Yes & $28(29.5)$ \\
\hline Alcohol abuse & \\
\hline No & $71(74.7)$ \\
\hline Yes & $24(25.3)$ \\
\hline
\end{tabular}


TABLE 2 (cont.) Clinical and lifestyle characterization of patients with type 2 diabetes mellitus.

\begin{tabular}{ll} 
Variables & $\mathbf{N}(\%)$ \\
\hline Family history of diabetes & \\
\hline No & $42(44.2)$ \\
\hline Yes & $53(55.8)$ \\
\hline Insulin treatment & $53(55.8)$ \\
\hline No & $42(44.2)$ \\
\hline Yes & \\
\hline Dietary control & $21(23.6)$ \\
\hline Regular & $68(74.4)$ \\
\hline Irregular & $16(17.8)$ \\
\hline Dietary guidance & $74(82.2)$ \\
\hline Yes & \\
\hline No & $69(72.6)$ \\
\hline Multidisciplinary monitoring & $26(27.4)$ \\
\hline Yes &
\end{tabular}

The mean and standard deviation of the metabolic parameters of patients with T2DM (weight, fasting blood glucose, HbA1c, total cholesterol, HDL-c, LDL-c, triglycerides) are presented in Table 3 . The mean fasting blood glucose of the participants was $144.07 \mathrm{mg} / \mathrm{dL}$, with a prevalence of $78 \%$ of altered glycemia. Also, $65 \%$ presented altered $\mathrm{HbA} 1 \mathrm{c}$ results. Regarding lipid profile, $43.2 \%$ had total cholesterol levels above $200 \mathrm{mg} / \mathrm{dL}, 64 \%$ had triglycerides > $150 \mathrm{mg} / \mathrm{dL}$, and 63\% had low HDL-c.

TABLE 3 Physiological parameters of patients with type 2 diabetes mellitus.

\begin{tabular}{|c|c|c|}
\hline Parameter & Mean \pm SD & Reference values for diabetics* \\
\hline Weight (kg) & $77.41 \pm 19.09$ & - \\
\hline Fasting blood & $144.07 \pm 60.46$ & $<110 \mathrm{mg} / \mathrm{dL}$ (goal for diabetics) \\
\hline glucose $(\mathrm{mg} / \mathrm{dL})$ & & $\begin{array}{l}<130 \mathrm{mg} / \mathrm{dL} \text { (tolerable for } \\
\text { diabetics) }\end{array}$ \\
\hline HbA1c (\%) & $7.81 \pm 1.78$ & $\begin{array}{l}\text { Close to } 7 \text { (acceptable for } \\
\text { diabetics) }\end{array}$ \\
\hline $\begin{array}{l}\text { Total cholesterol } \\
(\mathrm{mg} / \mathrm{dL})\end{array}$ & $177.12 \pm 38.74$ & $<200($ normal) \\
\hline $\mathrm{HDL}-\mathrm{c}(\mathrm{mg} / \mathrm{dL})$ & $47.02 \pm 13.85$ & $\begin{array}{l}>40 \text { (adequate for men) } \\
>50 \text { (adequate for women) }\end{array}$ \\
\hline LDL-c $(\mathrm{mg} / \mathrm{dL})$ & $104.04 \pm 31.74$ & 101 a 130 (normal) \\
\hline Triglycerides (mg/dL) & $162.12 \pm 85.04$ & $<150$ (adequate) \\
\hline $\begin{array}{l}\text { Systolic blood } \\
\text { pressure }(\mathrm{mmHg})\end{array}$ & $134.87 \pm 17.90$ & $<140$ (adequate for diabetics) \\
\hline $\begin{array}{l}\text { Diastolic blood } \\
\text { pressure }(\mathrm{mmHg})\end{array}$ & $80.63 \pm 8.18$ & $<90$ (adequate for diabetics) \\
\hline
\end{tabular}

The main complication among patients with T2DM was high blood pressure (HBP) (70.9\%). The frequency of cardiovascular diseases (1.2\%), diabetic retinopathy $(5.3 \%)$ and diabetic nephropathy (6.3\%) was low (Figure 1). In our study, considering HBP as the main complication among patients, our association analyses focused on the presence of this specific pathology.

Table 4 shows the result of bivariate regression analysis for factors associated with the presence of HBP in patients with T2DM. At the level of 0.20 , the following variables were associated with HBP and were included in the multiple analyses: age, marital status, ethnicity, time since diagnosis, family history of diabetes, insulin treatment, dietary control, nutritional monitoring, multidisciplinary monitoring and $\mathrm{HbA1c}$.

In the multiple analysis, insulin treatment $(\mathrm{p}=0.042)$ and multidisciplinary monitoring $(\mathrm{p}=0.050)$ were the variables positively associated with the presence of HBP in patients with T2DM. The estimated coefficients for these variables indicate that the adoption of insulin treatment and monitoring by a multidisciplinary team contribute to the increase of 2.88 and 0.335 units, respectively, in the risk of HBP (Table 5).

\section{Discussion}

T2DM and its chronic complications have become increasingly common. ${ }^{1,9,10}$ Thus, the importance of the survey carried out in our study, which contributes from a clinical point of view to the monitoring of diabetic patients. ${ }^{11}$ Monitoring the patient helps to improve adherence to treatment, to detect difficulties in following it, and to guide health professionals to provide continuous support and achieve goals, ${ }^{1,11}$ thus avoiding aggravation of chronic diseases such as T2DM.

The mean age of the diabetic patients in our study was 54 years, suggesting a relation between the increase in life expectancy and the presence of chronic pathologies in the population. ${ }^{1}$ Considering that patients were not young, the importance of early T2DM screening should be emphasized, since the insidious character means that patients can be affected well before diagnosis. ${ }^{12}$ Time since diagnosis is critical as it directly affects the development of comorbidities and the time of adherence to treatment. Thus, the longer the time to obtain a diagnosis, the lower the control of blood glucose and the greater the chance of developing complications. ${ }^{1,13}$

Our sample had a balanced ratio between men and women. We found that most of the patients had a partner, which can be a positive factor since structured families provide subsidies for patients with $\mathrm{T} 2 \mathrm{DM}$, thus contrib- 


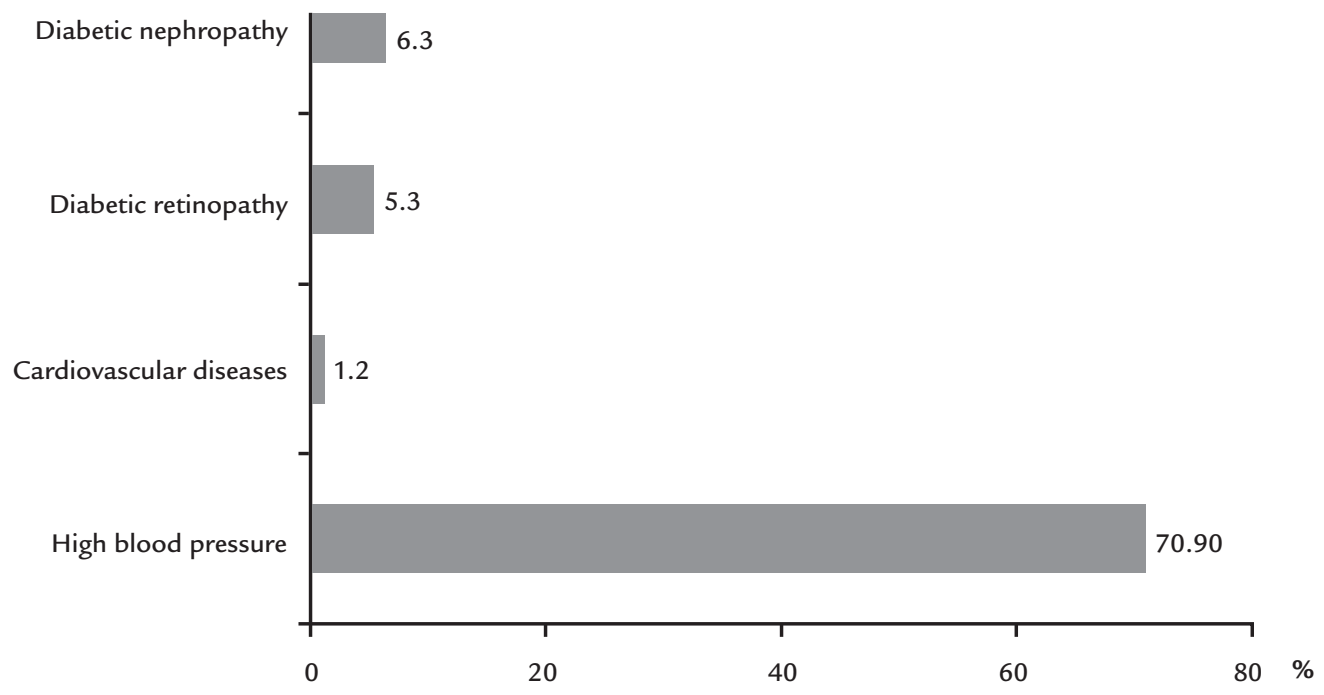

FIGURE 1 Frequencies of complications in patients with type 2 diabetes mellitus.

TABLE 4 Univariate analysis for the factors associated with the presence of high blood pressure in patients with type 2 diabetes mellitus.

Sociodemographics and lifestyle

HBP

N (\%)

p-value

Sex

Male $25(43.1)$

33 (56.9)

Female

\begin{tabular}{ll}
\hline 20 to 45 & $8(13.8)$ \\
\hline 46 & $50(86.2$ \\
\hline Marital status
\end{tabular}

Married/common-law $27(60.0)$
Single/divorced/widow(er) $18(40.0)$

Smoker

\begin{tabular}{lll} 
No & $37(71.2)$ & 0.955 \\
\cline { 1 - 2 } Yes & $15(28.8)$ & \\
\hline Alcohol abuse & & 0.061 \\
\hline No & $42(82.4)$ & \\
\hline Yes & $9(17.6)$ & \\
\hline
\end{tabular}

Clinical

Time since diagnosis (years)

\begin{tabular}{lll}
\hline$\leq 10$ & $22(38.6)$ & 0.022 \\
\hline$>10$ & $35(61.4)$ & 0.155 \\
\cline { 1 - 2 } Family history of diabetes & & \\
\cline { 1 - 2 } No & $29(50.0)$ & 0.002 \\
\hline Yes & $29(50.0)$ & \\
\hline Insulin treatment & $25(43.1)$ & \\
\hline Nes & $33(56.9)$ & \\
\hline
\end{tabular}


TABLE 4 (cont.) Univariate analysis for the factors associated with the presence of high blood pressure in patients with type 2 diabetes mellitus.

\section{Sociodemographics and lifestyle}

HBP

N (\%) $\quad$ p-value

Dietary control

\begin{tabular}{|c|c|c|}
\hline Regular & $10(18.5)$ & 0.161 \\
\hline Irregular & $44(81.5)$ & \\
\hline \multicolumn{3}{|c|}{ Dietary guidance } \\
\hline Yes & $7(12.7)$ & \multirow[t]{2}{*}{0.116} \\
\hline No & $48(87.3)$ & \\
\hline \multicolumn{3}{|c|}{ Multidisciplinary monitoring } \\
\hline Yes & $47(81.0)$ & \multirow[t]{2}{*}{0.021} \\
\hline No & $11(19.0)$ & \\
\hline \multicolumn{3}{|l|}{ Metabolic } \\
\hline \multicolumn{3}{|c|}{ Fasting blood glucose } \\
\hline Yes & $10(18.2)$ & \multirow[t]{2}{*}{0.589} \\
\hline No & $45(81.8)$ & \\
\hline \multicolumn{3}{|l|}{$\mathrm{HbA1c}$} \\
\hline Yes & $24(41.4)$ & \multirow[t]{2}{*}{0.026} \\
\hline No & $34(58.7)$ & \\
\hline \multicolumn{3}{|c|}{ Total cholesterol } \\
\hline Yes & $31(53.4)$ & \multirow[t]{2}{*}{0.403} \\
\hline No & $27(46.6)$ & \\
\hline \multicolumn{3}{|l|}{ HDL-c } \\
\hline Yes & $34(58.6)$ & \multirow[t]{2}{*}{0.251} \\
\hline No & $24(41.4)$ & \\
\hline \multicolumn{3}{|l|}{ LDL-c } \\
\hline Yes & $24(25.3)$ & \multirow[t]{2}{*}{0.341} \\
\hline No & $34(74.7)$ & \\
\hline \multicolumn{3}{|c|}{ Triglycerides } \\
\hline Yes & $18(31.0)$ & \multirow[t]{2}{*}{0.226} \\
\hline No & $40(69.0)$ & \\
\hline \multicolumn{3}{|c|}{ Systolic blood pressure } \\
\hline Yes & $39(67.2)$ & \multirow[t]{2}{*}{0.554} \\
\hline No & $19(32.8)$ & \\
\hline \multicolumn{3}{|c|}{ Diastolic blood pressure } \\
\hline Yes & $37(63.8)$ & \multirow[t]{2}{*}{0.515} \\
\hline No & $21(36.2)$ & \\
\hline
\end{tabular}

HBP: high blood pressure.

TABLE 5 Multiple logistic regression analysis for factors associated with the presence of high blood pressure in patients with type 2 diabetes mellitus.

Variables

OR (adjusted)

$95 \mathrm{Cl}$

p-value

Insulin treatment

\begin{tabular}{llll}
\hline No & 1 & & \\
\cline { 1 - 2 } Yes & 2.88 & $1.03-8.00$ & 0.042 \\
\cline { 1 - 3 } Multidisciplinary monitoring & & & 0.050 \\
\cline { 1 - 2 } & 1 & & \\
\hline No & 0.335 & $0.11-1.00$ & \\
\hline
\end{tabular}

OR: odds ratio; $95 \mathrm{Cl}$ : $95 \%$ confidence interval. 
uting to adherence to treatment. ${ }^{14}$ As for family history, $50 \%$ of the patients had first-degree relatives with diabetes, proving a genetic basis for the disease, although their prevalence on the environmental factors cannot be affirmed. Although the etiology of T2DM is not fully elucidated, it is known to have a multifactorial composition. ${ }^{2}$ Therefore, it is important to investigate the patient's social history and, if possible, to make the family a pillar of care that involves lifestyle change. ${ }^{14}$

Regarding lifestyle, most patients were non-smokers and non alcohol-dependent, which is a satisfactory result, since the association between smoking and limb amputations in diabetic patients is well known. ${ }^{15}$ Most did not maintain dietary control and did not follow the guidance of a dietitian. Studies indicate that healthy eating is one of the most difficult practices, in contrast to drug therapy, which, as found in our study, generally has good adherence. ${ }^{11,15}$ Non-adherence to diabetes treatment is a problem of known magnitude on the international and national scene that contributes to the low effectiveness of treatment and complications in the medium and long term and, consequently, to an increase in the demand for highly complex health services. ${ }^{11}$ It is evident, therefore, that primary care should greatly improve its activities of receiving these patients for multiprofessional treatment.

In our study, $92.6 \%$ of diabetic patients had glycemic indexes greater than $91 \mathrm{mg} / \mathrm{dL}$, and the mean in the population was high, reaching $144 \mathrm{mg} / \mathrm{dL}$. Glycated hemoglobin levels were also high, averaging $7.8 \%$. These data indicate that glycemic control was not performed as recommended by the Brazilian Society of Diabetes Mellitus (SBD, in the Portuguese acronym), which establishes the maximum value of $100 \mathrm{mg} / \mathrm{dL}$ for fasting blood glucose. There is, therefore, the need for treatment of our population, since adequate metabolic control either prevents the onset of chronic complications or delays their progression, particularly those of microangiopathic nature. ${ }^{2}$

Measures to prevent hypertension and dyslipidemia should be part of the treatment of patients with T2DM because they increase the risk of developing cardiovascular diseases, directly impacting morbidity and mortality rates. ${ }^{16}$ In our study, these parameters were altered, which requires attention to indicate the risk of developing a cardiovascular problem. Mortality due to cardiovascular disease progressively increases in a linear, continuous and independent manner with blood pressure values above $115 / 75 \mathrm{mmHg} .{ }^{17}$

HBP was the main complication described in our population. The Brazilian Society of Diabetes states that T2DM, hypertension and renal function are closely related. HBP can be both a cause and a consequence of kidney disease, and the combination of the two presents a high risk for cardiovascular disease. Thus, appropriate treatment of HBP helps to prevent cardiovascular disease, minimizes the progression of renal disease and diabetic retinopathy. Care involves practices such as regular physical activity, low-sodium diet, decreased consumption of alcoholic beverages and correct intake of prescribed antihypertensive medication. ${ }^{2}$

The combination of complications with the variables insulin use and multidisciplinary monitoring refers to the advanced stage of the disease since patients with T2DM are more susceptible to chronic complications. Thus, T2DM progression time may lead to more risks for the development of microvascular complications in general. ${ }^{18}$ It should also be kept in mind that the pathophysiological process of aging alone can cause atherosclerosis, farsightedness and immune changes that may increase the prevalence of complications. ${ }^{18}$

Broadly speaking, the results do not allow the establishment of cause and effect relations but indicate that patients with T2DM in our study, many with HBP, had irregular glycemic control, used hypoglycemic agents but did not make dietary adjustments. These factors directly compromise the quality of life of diabetic individuals and make the pathology difficult to control. Therefore, measures that show patients the severity of diabetes and the possible consequences of a lack of adequate treatment should be adopted in our population.

Since there is no cure for diabetes, its best treatment is primary prevention, encouraging the at-risk population to have healthy lifestyle habits and performing periodic screening. Responsibility for health promotion should not be limited to health professionals. Public policies that need to be implemented include those aimed at improving access to health services, empowering patients to understand the disease and learn self-care skills. ${ }^{19,20}$ As for secondary prevention, it is important to monitor and encourage behavioral changes, because even when insulin is used, glycemic control may be unsatisfactory if the individual does not adopt a healthy lifestyle. ${ }^{2}$

A last aspect to be considered refers to the limitations of our study. Some data from the medical records were incomplete or absent, lacking the necessary information to complete the questionnaires. In addition, anamnesis and clinical examination were not standardized, making it difficult to monitor clinical alterations. Finally, there was no specific periodicity for patients attending medical appointments, and in some cases the amount of follow-up data was too low or non-existent. These difficulties led to the exclusion of several medical records, thus reducing the sample. 


\section{Conclusion}

We identified as the main complication in the diabetic population included in our study the incidence of HBP. In addition, we have shown that the main associated risk factors were, in general, insulin use and multidisciplinary team monitoring. The joint occurrence of these factors may indicate an advanced stage of the disease and greater exposure to chronic complications.

The studied population also showed irregular glycemic control, despite the use of hypoglycemic medication, and irregular diet. Thus, we suggest primary prevention actions for this population, such as strict monitoring of blood glucose and blood pressure, multiprofessional follow-up, adherence to drug therapy, physical exercise and dietary monitoring, in addition to the active participation of the family in the treatment of the disease and a stronger bond with the health unit.

\section{Resumo}

Fatores de risco e complicações em pacientes de ambulatório com diabetes tipo 2

Objetivo: $\mathrm{O}$ estudo investigou pacientes com diabetes tipo 2 (DM2) atendidos em um hospital universitário de Montes Claros (MG) a fim de estimar a prevalência de fatores de risco e sua associação com complicações da diabetes.

Método: Pesquisa quantitativa, documental, retrospectiva e analítica. Foram analisadas as fichas médicas de 95 adultos portadores de DM2 atendidos no ambulatório do hospital entre 2011 e 2015. Os dados foram coletados de acordo com um questionário estruturado incluindo variáveis sociodemográficas, antropométricas e bioquímicas e aspectos clínicos e de estilo de vida. As análises de associação entre variáveis de fatores de risco e presença de complicações foram feitas por meio da regressão logística. Resultados: Com média de 54 anos de idade, a população estudada tinha controle glicêmico irregular, fazia uso de hipoglicemiantes e não adotava um estilo de vida saudável. A principal complicação reportada foi hipertensão arterial, presente em $70,9 \%$ dos casos. A prevalência de complicações associou-se positivamente com adoção de tratamento insulínico $(\mathrm{p}=0,042)$ e acompanhamento multidisciplinar $(\mathrm{p}=0,050)$.

Conclusão: As associações encontradas refletem a condição de pacientes que já tratam a diabetes e suas complicações, principalmente a hipertensão arterial. Características da população indicam a necessidade de melhoria do acompanhamento clínico e o incentivo à adoção de hábitos comportamentais saudáveis.
Palavras-chave: diabetes mellitus tipo 2, complicações do diabetes, fatores de risco.

\section{References}

1. Schmidt MI, Duncan BB, Azevedo e Silva G, Menezes AM, Monteiro CA Barreto SM, et al. Chronic non-communicable diseases in Brazil: burden and current challenges. Lancet. 2011; 377(9781):1949-61.

2. Oliveira JEP, Vencio S (org.). Diretrizes da Sociedade Brasileira de Diabetes, 2015-2016. São Paulo: A.C. Farmacêutica; 2016.

3. Schmidt MI, Hoffmann JF, Diniz MFS, Lotufo PA, Griep RH, Bensenor IM, et al. High prevalence of diabetes and intermediate hyperglycemia - the Brazilian longitudinal study of adult health (ELSA-Brasil). Diabetol Metab Syndr. 2014; 6:123.

4. American Diabetes Association. Diagnosis and classification of diabetes mellitus. Diabetes Care. 2015; 38(Suppl 1):S8-S16.

5. Queiroz PC, Aguiar DC, Pinheiro RP, Moraes CC, Pimentel IRS, Ferraz CLH, et al. Prevalência das complicações micro e macrovasculares e de seus fatores de risco em pacientes com diabetes mellitus e síndrome metabólica. Rev Soc Bras Clin Med. 2011; 9(4):254-8.

6. Cenci DR, Silva MD, Gomes EB, Pinheiro HA. Análise do equilíbrio em pacientes diabéticos por meio do sistema F-Scan e da Escala de Equilíbrio de Berg. Fisioter Mov. 2013; 26(1):55-61.

7. Oliveira AF, Valente JG, Leite IC, Schramm JMA, Azevedo AR, Gadelha AMJ Global burden of disease attributable to diabetes mellitus in Brazil. Cad Saúde Pública. 2009; 25(6):1234-44.

8. Santos JC, Moreira TMM. Fatores de risco e complicações em hipertensos/ diabéticos de uma regional sanitária do nordeste brasileiro. Rev Esc Enferm. 2012; 46(5):1125-32.

9. International Diabetes Federation. IDF Diabetes Atlas. 7. ed. Brussels: International Diabetes Federation; 2015.

10. Pedras S, Carvalho R, Pereira MG. Sociodemographic and clinical characteristics of patients with diabetic foot ulcer. Rev Assoc Med Bras. 2016; 62(2):171-8.

11. Arrelias CCA, Faria HTG, Teixeira CRS, Santos MA, Zanetti ML. Adherence to diabetes mellitus treatment and sociodemographic, clinical and metabolic control variables. Acta Paul Enferm. 2015; 28(4):315-22.

12. Pedrosa DR, Lemos EO, Gonçalves DCS, Raniéri PSG, Pires CAA, Paiva VS Prevalência de retinopatia diabética em pacientes atendidos pela Estratégia Saúde da Família no município de Ananindeua-PA. Rev Bras Med Fam Comunidade. 2013; 8(26):58-63

13. Conselho Nacional de Saúde (Brasil). Resolução no 466, de 12 de dezembro de 2012. Brasília (DF): Ministério da Saúde; 2012 [cited 2016 Aug 1] Available from: http://www.conselho.saude.gov.br/resolucoes/2012/ Reso466.pdf.

14. Costa JA, Balga RSM, Alfenas RCG, Cotta RMM. Promoção da saúde e diabetes: discutindo a adesão e a motivação de indivíduos diabéticos participantes de programas de saúde. Ciênc Saúde Coletiva. 2011; 16(3):2001-9.

15. Przysienzny A, Rodrigues KF, Santiago LH, Silva MCV. Características sociodemográficas de pacientes com diabetes mellitus portadores de pé diabético e ou retinopatia diabética atendidos em 16 unidades de Estratégia de Saúde da Família de Blumenau. Arq Catarin Med. 2013; 42(1):76-84

16. Pinho L, Aguiar APS, Oliveira MR, Barreto NAP, Ferreira CMM. Hipertensão e dislipidemia em pacientes diabetes mellitus tipo 2: uma revisão integrativa. Rev Norte Mineira Enferm. 2015; 4(1):87-101.

17. Sociedade Brasileira de Cardiologia; Sociedade Brasileira de Hipertensão; Sociedade Brasileira de Nefrologia. VI Diretrizes Brasileiras de Hipertensão. Arq Bras Cardiol. 2010; 95(Suppl 1):1-51.

18. Santos AL, Cecílio HPM, Teston EF, Arruda GO, Peternella FMN, Marcon SS. Complicações microvasculares em diabéticos tipo 2 e fatores associados: inquérito telefônico de morbidade autorreferida. Ciênc Saúde Coletiva. 2015; 20(3):761-70

19. Zacharias FCM, Gomide MFS, Carneiro TSG, Pinheiro ALS, Bulgarelli AF, Lemos IV, et al. Determinantes da organização da atenção em diabetes mellitus na satisfação do usuário. Medicina. 2014; 47(2):177-84.

20. Gomides DS, Villas-Boas LCG, Coelho ACM, Pace AE. Self-care of people with diabetes mellitus who have lower limb complications. Acta Paul Enferm. 2013; 26(3):289-93 